Article

\title{
Probing the Release of Bupropion and Naltrexone Hydrochloride Salts from Biopolymeric Matrices of Diverse Chemical Structures
}

\author{
Angeliki Siamidi (D, Aikaterini Dedeloudi and Marilena Vlachou *(D) \\ Division of Pharmaceutical Technology, Department of Pharmacy, School of Health Sciences, \\ National and Kapodistrian University of Athens, 15784 Athens, Greece; asiamidi@pharm.uoa.gr (A.S.); \\ dedeloud@pharm.uoa.gr (A.D.) \\ * Correspondence: vlachou@pharm.uoa.gr; Tel.: +30-210-727-4674
}

check for

updates

Citation: Siamidi, A.; Dedeloudi, A.; Vlachou, M. Probing the Release of Bupropion and Naltrexone

Hydrochloride Salts from

Biopolymeric Matrices of Diverse Chemical Structures. Polymers 2021, 13, 1456. https://doi.org/10.3390/ polym13091456

Academic Editor: José Antonio Gabaldón Hernández

Received: 29 March 2021

Accepted: 28 April 2021

Published: 30 April 2021

Publisher's Note: MDPI stays neutral with regard to jurisdictional claims in published maps and institutional affiliations.

Copyright: (c) 2021 by the authors. Licensee MDPI, Basel, Switzerland. This article is an open access article distributed under the terms and conditions of the Creative Commons Attribution (CC BY) license (https:/ / creativecommons.org/licenses/by/ $4.0 /)$.
Abstract: In the last decades, the notion of including excipients in the formulations, as inert substances aiding production processes, has changed and they are recently viewed as multifunctional discrete entities. It is now well documented that excipients serve several roles, spreading from the stabilization and modified release, to providing biocompatible properties and targeting moieties. The aim of this study was to develop matrix-based oral drug delivery systems of bupropion hydrochloride $(\mathrm{BUP} \cdot \mathrm{HCl})$ and naltrexone hydrochloride $(\mathrm{NTX} \cdot \mathrm{HCl})$, suitable for releasing these active substances in a modified manner, providing a stable level of drug release, which is simultaneously therapeutically effective and non-toxic, thus reducing side effects, after a single dose administration, throughout the gastrointestinal tract. The new formulations, employing hydroxypropylmethycellulose (HPMC $\mathrm{K} 15 \mathrm{M}$ ) (a cellulosic polymer, which, generally hydrates to form a gelatinous layer that is critical to prevent wetting and rapid drug release from the matrices), poly(methacylic acid-co-ethyl acrylate) 1:1 (Eudragit ${ }^{\circledR}$ L100-55: effective for site specific drug delivery in intestine), poly(ethylene oxide) (PEO) $\left(7 \times 10^{6}\right.$ : a high molecular weight polymer, water-soluble, in micro-granular powder form), as the rate controlling polymers, were chosen to lead to a "soothing out" release pattern of these drugs, at $0 \leq \mathrm{t} \leq 120 \mathrm{~min}$. Moreover, the release of the two drugs from the ulvan-based tablets, was found to follow the desired profile, throughout the entire course of the dissolution experiments.

Keywords: bupropion; naltrexone; modified release; ulvan; matrix tablet; biopolymers

\section{Introduction}

Bupropion hydrochloride, ( \pm )-1-(3-chlorophenyl)-2-[(1,1-dimethylethyl)amino]-1propanone, hydrochloride) (BUP. $\mathrm{HCl}$ ), is a BCS Class I drug (high solubility and high permeability) [1,2] with a low molecular weight (molecular weight of its $\mathrm{HCl}$ salt $=276.2 \mathrm{~g} / \mathrm{mol}$ ), which has been in therapeutic use, as an antidepressant, since 1989 [3]. As far as the physicochemical properties of BUP. $\mathrm{HCl}$ are concerned, it is characterized by two crystalline polymorphic structures, which appear to be enantiotropically related [4] and has an asymmetric center, resulting to two enantiomers, the $(2 R)$-bupropion and the (2S)-bupropion (Scheme 1). Although the pure enantiomers of BUP.HCl have been successfully synthesized, rapid racemization occurs in aqueous solution. Therefore, this drug is available in the market, as a racemic mixture [5,6].

Pharmacologically, BUP. $\mathrm{HCl}$, which is an aminopropiophenone, is characterized as a dopamine/norepinephrine reuptake inhibitor (NDRI) [7]. It is a selective inhibitor of neuronal reuptake of catecholamines (noradrenaline and dopamine), with negligible action of indolamine reuptake (serotonin). It is also a potent, non-competitive antagonist of central nicotinic receptors. Nevertheless, the exact mechanism of action of BUP. $\mathrm{HCl}$ remains unclear [5]. It was originally classified as an "atypical" antidepressant, due to its different effects, from conventional antidepressants, such as the monoamine oxidase inhibitors, 
the tricyclic antidepressants, and the selective serotonin reuptake inhibitors [8]. BUP. $\mathrm{HCl}$ is most commonly used to confront major depression, seasonal affective disorder (SAD), smoking cessation, attention deficit hyperactivity disorder and eating disorders [9]. Moreover, it is extensively metabolized in humans, by liver enzymes (mainly CYP2B6), into three metabolites: hydroxybupropion, threo-hydroxybupropion and erythro-hydroxybupropion, which have been suggested to contribute and/or be responsible for its antidepressant properties. Hydroxybupropion and threo-hydroxybupropion are the major metabolites in humans, while the erythro-hydroxybupropion, is formed in smaller amounts [10].

Immediate-release BUP. $\mathrm{HCl}$ (Wellbutrin ${ }^{\circledR} 75 \mathrm{mg}, 100 \mathrm{mg}$ ) is commercially available since 1989 and is usually a well-tolerated antidepressant. However, seizures appeared in approximately $0.4 \%$ of patients treated at daily doses up to $450 \mathrm{mg}$. In order to reduce the adverse side effects, sustained-release Wellbutrin ${ }^{\circledR}$ SR (100 mg, 150 mg, $200 \mathrm{mg}$ and $300 \mathrm{mg}$ ) has been developed. Wellbutrin ${ }^{\circledR}$ SR tablets comprise of an hydroxypropylmethycellulose HPMC-based matrix core containing, cysteine hydrochloride, as a stabilizer, and film coating [11-13].

Naltrexone [(4R,4aS,7aR,12bS)-3-(cyclopropylmethyl)-4a,9-dihydroxy-2,4,5,6,7a,13hexahydro- $1 \mathrm{H}-4,12$-methanobenzofuro[3,2-e] isoquinolin-7-one] (NTX. $\mathrm{HCl}$, Scheme 1 ) is an opioid receptor antagonist and a synthetic derivative of oxymorphone [14,15]. It has the potential to bind with $\kappa, \delta$ and $\mu$ receptors in the central nervous system (CNS). However, NTX $\cdot \mathrm{HCl}$ shows a higher affinity in binding with $\mu$ receptors and acts competitively with the endogenous opioids of the CNS [16]. It is used in pharmacotherapy against a plethora of human disorders, with the most significant being, alcohol and heroin dependence, schizophrenia, obesity and eating disorders $[17,18]$. Naltrexone is classified as a BCS IV drug (low solubility and low permeability) [19] and is absorbed rapidly after following per os administration. The metabolism of NTX. $\mathrm{HCl}$ occurs in the liver, producing an active metabolite, the 6- $\beta$-naltrexol; the elimination of naltrexone and 6- $\beta$-naltrexol is taking place primarily in the kidneys [20-22].<smiles>C[C@H](NC(C)(C)C)C(=O)c1cccc(Cl)c1</smiles>

(a)<smiles>C[C@H](NC(C)(C)C)C(=O)c1cccc(Cl)c1</smiles>

(b)

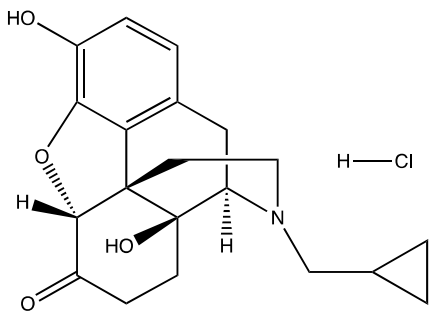

(c)

Scheme 1. Chemical structures of: (a) (2R)-bupropion. $\mathrm{HCl}$, (b) (2S)-bupropion $\mathrm{HCl}$ and (c) naltrexone $\mathrm{HCl}$.

Biopolymers, when used as pharmaceutical excipients, play an important role in drug delivery technology. Polymeric drug delivery systems enable the introduction of a therapeutic substance into the body, not only by improving its safety and efficacy, but also by controlling the rate, time, and site of release of the drug in the body. Polymers can provide modified release of both hydrophilic and hydrophobic drugs. The mechanisms of drug release can be linked to drug diffusion, dissolution and degradation of the matrix system, where the drug is embedded. 
The development of drug delivery systems, that are based on natural and/or synthetic polymers, have rendered high expectations in the pharmaceutical field. Natural polymers can be of various sources, marine polysaccharides, being amongst them. Such a biopolymer, of marine origin, is ulvan, which is isolated from green algae (Ulva lactuca and Enteromorpha), and is comprised of a group of highly sulfated polysaccharides with acidic properties, mainly composed with rhamnose 3-sulfate, xylose 2-sulfate, glucuronic acid and iduronic acid [23]. Its unique chemical structure is responsible for several biological and therapeutic activities, as, for example, antiviral, antibacterial, immunostimulatory, antioxidant, antihyperlipidemic and anticoagulant [24].

Moreover, it is bio-compatible, non-toxic, bio-degradable and stimuli-responsive polymer, characterized as a suitable and optional excipient in designing and formulating drug delivery systems with a release that can be effectively controlled [25]. Ulvan is a multifunctional and multi-responsive polysaccharide, thus the structural organization of its polymeric chains and consequently its gel formation can be modified in $\mathrm{pH}-$, ion- and temperature-modified conditions, defining the final release rate of the active pharmaceutical ingredient (API) [26,27]. In particular, when ulvan is present in a low or a neutral $\mathrm{pH}$ aqueous medium is immediately transformed to a condensed bead-like conformation due to the hydrophobic properties of rhamnose [28]. Moreover, in a simultaneous presence of counterions, ulvan polymeric chains immediately form aggregates, characterized by low viscosity and rheological properties, influencing considerably the release rate of drug delivery systems [29]. Consequently, in drug delivery, ulvan can alter the release of the therapeutic agent by forming either physical and/or chemical hydrogels with multifunctional properties [30].

The aim of the present study is to communicate our findings on the BUP. $\mathrm{HCl}$ and NTX. $\mathrm{HCl}$ modified release from solid dosage forms, using polymers of diverse origins, en route to our future task to develop oral compounded formulations of these two drugs, capable of confronting the obesity menace.

Modified release formulations are advantageous, as they maintain the concentration of the administered drugs within the therapeutically effective range, thus decreasing the dosing intervals [31,32]. BUP. $\mathrm{HCl}$ is, as already mentioned, an antidepressant used for smoking cessation and to treat a variety of conditions, including depression and other men$\mathrm{tal} / \operatorname{mood}$ disorders. Antidepressants can help in preventing suicidal attempts and provide other important benefits [33]. On the other hand, NTX. $\mathrm{HCl}$ is a drug substance mainly used in alcohol/heroin dependence and for the treatment of problems, such as eating behavior disorders (e.g., bulimia and anorexia nervosa), obesity and erectile dysfunction [15,17]. Both of these active substances could benefit from modified release tablet formulations, as the commercially available BUP. $\mathrm{HCl}$ product, Wellbutrin ${ }^{\circledR} \mathrm{XR}$, exhibits a satisfactory release (almost 67\%) in the intestinal environment, but, no release at the stomach $\mathrm{pH}$. The same holds true for naltrexone hydrochloride, which to the best of our knowledge, is mainly administered, as a formulation for depot injection, containing $380 \mathrm{mg}$ of the medication per vial (Vivitrol $\left.{ }^{\circledR}\right)$ [34]. The new formulations, employing hydroxypropylmethycellulose (HPMC K15M) (a cellulosic polymer, which, generally hydrates to form a gelatinous layer that is critical to prevent wetting and rapid drug release from the matrices), poly(methacylic acid-co-ethyl acrylate) 1:1 (Eudragit ${ }^{\circledR}$ L100-55: effective for site specific drug delivery in intestine), poly(ethylene oxide) $(\mathrm{PEO})\left(7 \times 10^{6}:\right.$ a high molecular weight polymer, water-soluble, in micro-granular powder form) and ulvan, as the rate controlling polymers, could lead to a "soothing out" release pattern of these drugs, at $0 \leq \mathrm{t} \leq 120 \mathrm{~min}$.

\section{Materials and Methods}

\subsection{Materials}

NTX. HCl (MW: $377.87 \mathrm{~g} / \mathrm{mol},>98.0 \%$ purity) and BUP. $\mathrm{HCl}$ (MW: 276.20, $>98.0 \%$ purity) were purchased from Tokyo Chemical Industry (Japan). Wellbutrin ${ }^{\circledR}$ XR $150 \mathrm{mg}$ (Lot.No. 19F007, GlaxoSmithKline, Industrial \& Commercial S.A.) and Wellbutrin ${ }^{\circledR}$ XR $300 \mathrm{mg}$ (Lot.No. F78H, GlaxoSmithKline, Industrial \& Commercial S.A.), were donated from a community phar- 
macy store (T. Papasandas, Athens, Greece). HPMC K15M and PEO (MW: $7 \times 10^{6} \mathrm{~g} / \mathrm{mol}$ ) were supplied from Sigma-Aldrich (Steinheim, Germany). Eudragit ${ }^{\circledR}$ L100-55 was obtained from Rohm GmbH Pharma Polymers (Darmstadt, Germany). Ulvan (Cat. No. YU11689) was purchased from Carbosynth ${ }^{\circledR}$ Ltd. (Berkshire, UK) and magnesium stearate was supplied by Riedel-De Haen (Hannover, Germany). All chemicals were of reagent grade and used in this study without further purification.

\subsection{Methods}

2.2.1. Preparation of BUP $\cdot \mathrm{HCl}$ and $\mathrm{NTX} \cdot \mathrm{HCl}$ Modified Release Tablets

Matrix tablets of the APIs (BUP. $\mathrm{HCl}$ and NTX. $\mathrm{HCl}$ ) were prepared by blending and compressing them with a variety of excipients (vide Table 1, Figure 1). In detail, the APIs and excipients (HPMC, PEO, Eudragit ${ }^{\circledR}$ L100-55 and ulvan) were blended in a laboratory scale powder blender at $32 \mathrm{rpm}$ for $10 \mathrm{~min}$. Afterwards, the lubricant, magnesium stearate, was added and mixing was continued for 5 more minutes. The powder mixture was accurately weighed $(200 \mathrm{mg})$, loaded on a $10 \mathrm{~mm}$ diameter dye and directly compressed, using a hydraulic press (Maassen type, MP 150); loading compression force (5.00-5.50 tons).

Table 1. Composition of $\mathrm{BUP} \cdot \mathrm{HCl}$ and $\mathrm{NTX} \cdot \mathrm{HCl}$ tablet formulations (mg).

\begin{tabular}{|c|c|c|c|c|c|c|c|c|c|c|c|c|c|c|}
\hline Ingredients & B1 & B2 & B3 & B4 & B5 & B6 & B7 & N1 & N2 & N3 & N4 & N5 & N6 & N7 \\
\hline BUP HCl & 75 & 75 & 75 & 75 & 75 & 75 & 75 & - & - & - & - & - & - & - \\
\hline NTX HCl & - & - & - & - & - & - & - & 8 & 8 & 8 & 8 & 8 & 8 & 8 \\
\hline $\begin{array}{c}\text { Eudragit }^{\circledR} \\
\text { L100-55 }\end{array}$ & 48 & 75 & 123 & 48 & 75 & - & - & 74 & 116 & 190 & 74 & 116 & - & - \\
\hline HPMC K15M & 75 & 48 & - & - & - & - & - & 116 & 74 & - & - & - & - & - \\
\hline $\operatorname{PEO}\left(7 \times 10^{6}\right)$ & - & - & - & 75 & 48 & 123 & 75 & - & - & - & 116 & 74 & 190 & 116 \\
\hline Ulvan & - & - & - & - & - & - & 48 & - & - & - & - & - & - & 74 \\
\hline Mg. Stearate & 2 & 2 & 2 & 2 & 2 & 2 & 2 & 2 & 2 & 2 & 2 & 2 & 2 & 2 \\
\hline TOTAL & 200 & 200 & 200 & 200 & 200 & 200 & 200 & 200 & 200 & 200 & 200 & 200 & 200 & 200 \\
\hline
\end{tabular}

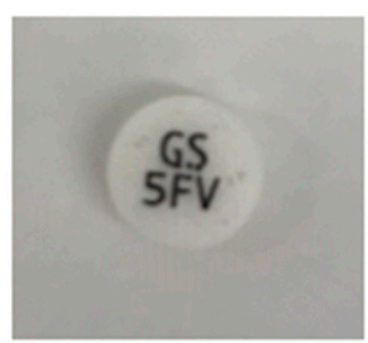

(a)

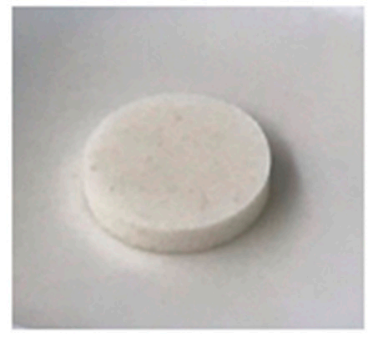

(c)

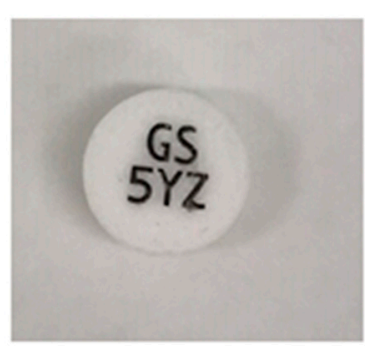

(b)

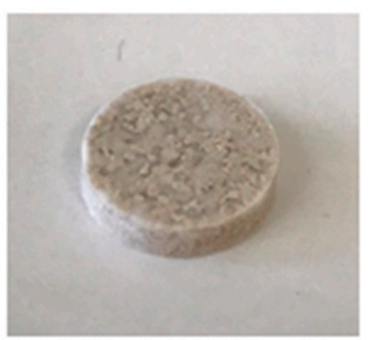

(d)

Figure 1. Tablet formulations of: (a) Wellbutrin ${ }^{\circledR} \mathrm{XR} 150 \mathrm{mg}$, (b) Wellbutrin ${ }^{\circledR} \mathrm{XR} 300 \mathrm{mg}$, (c) bupropion $\cdot \mathrm{HCl}$ and (d) naltrexone $\cdot \mathrm{HCl}$.

\subsubsection{Post Compression Parameters}

Thickness Test: The thickness of the tablets was measured using a Vernier calipers scale [35]. 
Hardness Test: The hardness of the tablets was determined using an Erweka hardness tester (Erweka, typeTBH28). The force applied was equal to breaking the tablet in a diametric compression. The surface hardness of each tablet is expressed in N [35].

\subsubsection{In Vitro Dissolution Studies}

The dissolution tests were carried out in a tablet dissolution test apparatus USP type II (Pharmatest, Hainerp, Germany) (paddle method). The experiments were performed in two different aqueous media: for the first $2 \mathrm{~h}, 450 \mathrm{~mL}$ of $0.2 \mathrm{M} \mathrm{HCl}$ solution (pH 1.2) was used to simulate the stomach $\mathrm{pH}$, and to that $450 \mathrm{~mL}$ of $0.14 \mathrm{M} \mathrm{K}_{2} \mathrm{HPO}_{4}$ solution ( $\mathrm{pH}$ 9) was then added, to have the required composition of the next phase, which simulates the enteric $\mathrm{pH}$ ( $\mathrm{pH}$ 6.8, final volume $900 \mathrm{~mL}$ ). [36].

The temperature of the dissolution medium was maintained at $37 \pm 0.5^{\circ} \mathrm{C}$. The tablet was placed in the bottom of a vessel, equipped with paddles, under sink conditions, and the apparatus was operated at $50 \mathrm{rpm}$. Samples were withdrawn in predetermined time intervals and the withdrawn volume of the medium was replenished. The withdrawn samples were filtered and analyzed in a Perkin-Elmer UV spectrophotometer (Norwalk, CT) at $\lambda_{\max }=251 \mathrm{~nm}$ (for BUP. $\mathrm{HCl}$ ) and at $\lambda_{\max }=281 \mathrm{~nm}$ (for NTX.HCl). The \% dissolution curve was determined according to the calibration curve of the corresponding API. All experiments were carried out six-fold $(n=6)$.

\subsubsection{Methods to Compare Dissolution Profiles}

In order to compare the dissolution profiles, graphs of $\%$ drug release vs. time were constructed (Figures 2 and 3) and the Dissolution Efficiency \% [D.E. (\%)] value was estimated. According to Khan (1975) [37], D.E. (\%) is a useful parameter for the evaluation of dissolution in vitro and is calculated from the following equation:

$$
\text { D.E. }(\%)=\frac{\int_{t_{1}}^{t_{2}} y d t}{y_{100}\left(t_{2}-t_{1}\right)} \times 100
$$

where, $y$ is the percentage of dissolved product and D.E. (\%) the area under the dissolution curve between time points $t_{1}$ and $t_{2}$, expressed as a percentage of the curve at maximum dissolution $\mathrm{y}_{100}$, over the same time period. Dissolution efficiency, which takes into account the dissolution profile as a whole, was employed to interrelate dissolution with the other variables used in this study.

Furthermore, $t_{20 \%}, t_{50 \%}$ and $t_{90 \%}$, as well as the mean dissolution time (MDT) values were estimated. The $t_{20}, t_{50 \%}$ and $t_{90 \%}$, values refer to the time, where the $20 \%, 50 \%$ and $90 \%$ of the active substance is released. MDT is the value used to characterize the drug release rate from a dosage form and the following is used to derive an estimate of MDT from experimental dissolution data [38]:

$$
M D T=\frac{A B C}{W_{\infty}}
$$

where, $\mathrm{W}_{\infty}$ is the maximum amount of the drug substance that is dissolved, and $\mathrm{ABC}$ is the area between the drug dissolution curve and its asymptote.

The in vitro release data were fitted to the Korsmeyer-Peppas equation:

$$
\frac{M_{t}}{M_{\infty}}=K t^{n}
$$

where, $M_{t}$ and $M_{\infty}$ denote the absolute cumulative amount of drug released at time $t$ and infinite time, respectively, $k$ the release rate constant and $n$ the diffusion coefficient. This equation is only valid for the first $60 \%$ of the fractional release [39]. In the case of cylindrical tablets, $n \leq 0.45$ corresponds to a Fickian diffusion release (case I diffusional), $0.45<n<0.89$ to an anomalous transport, and $n=0.89$ to zero order (case II) release kinetics. 


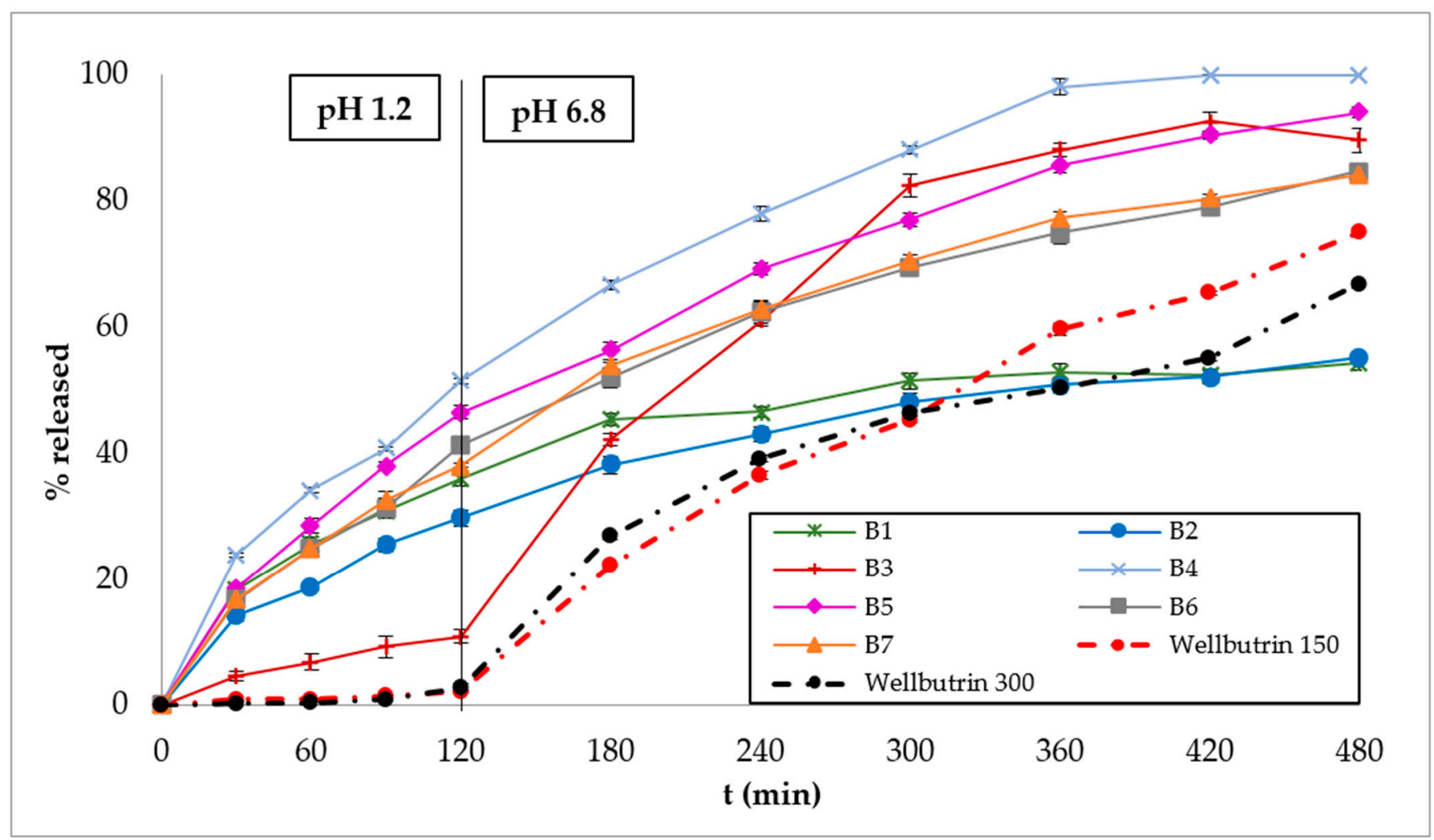

Figure 2. In vitro \% release of bupropion hydrochloride (BUP. $\mathrm{HCl})$ and the commercially available product (Wellbutrin ${ }^{\circledR} \mathrm{XR}$ 150 and $300 \mathrm{mg}$ ) vs. time Figure $1.2(0-120 \mathrm{~min})$ and at pH 6.8 (120-480 $\mathrm{min})$. The results denote the mean value $(n=6, \mathrm{SD}<2)$.

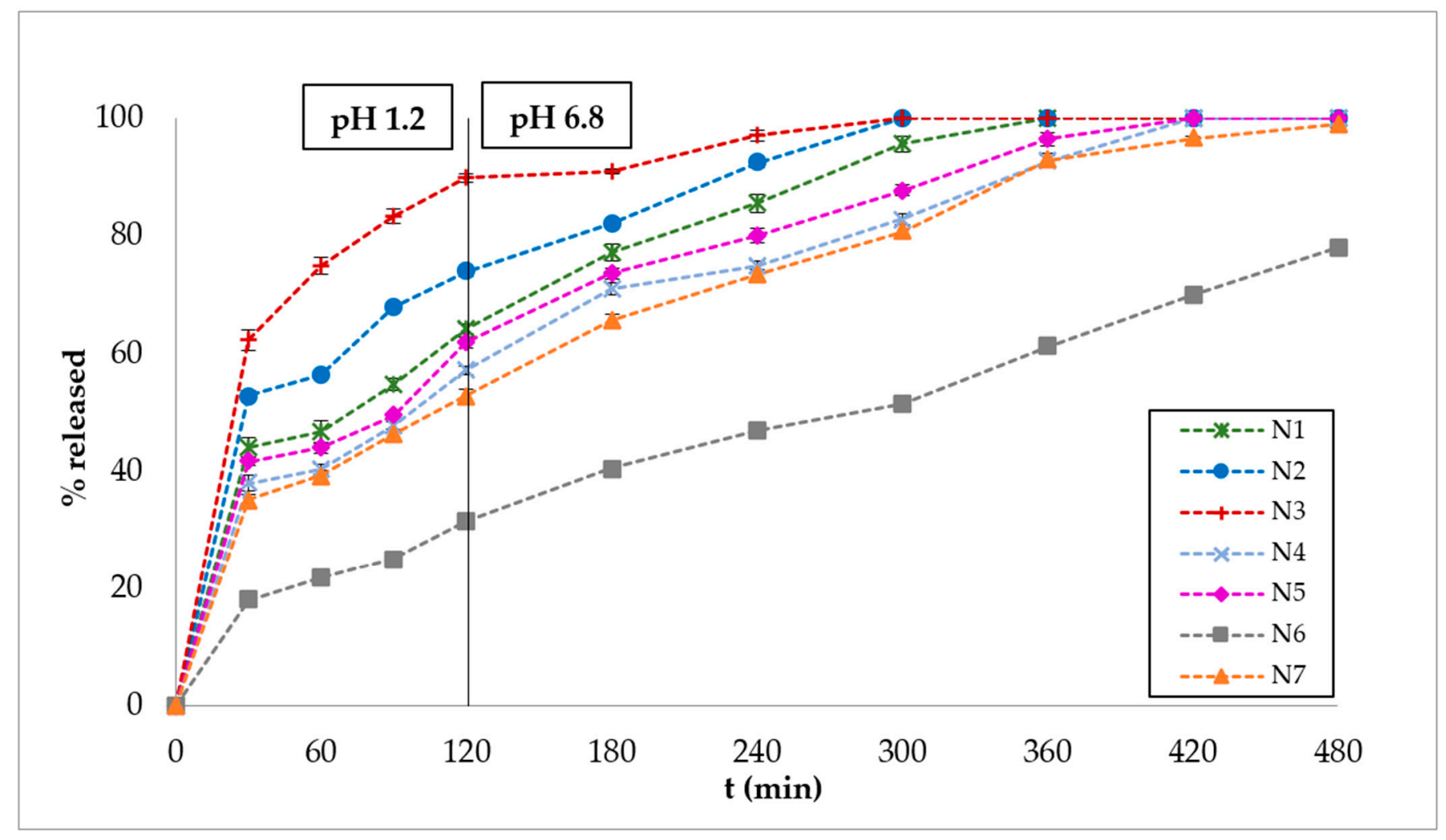

Figure 3. In vitro \% release of naltrexone hydrochloride $(\mathrm{NTX} \cdot \mathrm{HCl})$ vs. time from different tablet formulations at $\mathrm{pH} 1.2$ $(0-120 \mathrm{~min})$ and at $\mathrm{pH} 6.8(120-480 \mathrm{~min})$. The results denote the mean value $(n=6, \mathrm{SD}<2)$. 


\subsubsection{Anova-Based Analysis}

D.E. (\%) results were expressed as the mean \pm standard deviation (SD) and analyzed using the Tukey's post hoc test for this ANOVA test ( $p<0.05$ for significantly different results).

\subsubsection{Model-Independent Analysis of Dissolution Profiles}

Comparison indices, such as the difference factor $\left(f_{1}\right)$ and similarity factor $\left(f_{2}\right)$, were used to compare the dissolution profiles of the APIs [40,41].

\subsubsection{Polymer Erosion Studies}

Polymer erosion studies were also carried out, as the degree of polymer erosion is a characteristic, which may affect, considerably, the polymer behavior and therefore, drug release. Pre-weighed matrix tablets were introduced into the dissolution apparatus, under the standard set of conditions, specified for the release rate studies. The tablets were withdrawn using a small basket at selected time intervals and placed in an oven at $45^{\circ} \mathrm{C}$, for $24 \mathrm{~h}$. The dried tablets were cooled down in a desiccator and then weighed. This process was repeated until a constant weight was achieved (final dry weight). Six different tablets were measured, at each time point, and fresh tablets were used for each individual time point. The extent of erosion (E) was determined by the following equation:

$$
\mathrm{E} \%=\frac{100\left(W_{i}-W_{f}\right)}{W_{i}}
$$

where, $W_{i}$ is the initial starting dry weight and $W_{f}$ is the final dry weight of the same dried and partially eroded tablet, respectively [42].

\subsubsection{Disintegration Studies}

The disintegration process is specifically critical for immediate-release dosage forms, which are designed to fully disintegrate and dissolve upon exposure to physiological fluids within a short period of time ( 2.5 to $10 \mathrm{~min}$ ). In the present study, the tablets were designed to provide a modified release profile, and therefore, the time to disintegrate would be much higher than $10 \mathrm{~min}$, according to excipient properties, which allow tablet disintegration in a neutral $\mathrm{pH}$ aqueous media $[43,44]$.

\section{Results}

Tablet formulations of Wellbutrin ${ }^{\circledR}$ XR $150 \mathrm{mg}$, Wellbutrin ${ }^{\circledR}$ XR $300 \mathrm{mg}$, bupropion $\mathrm{HCl}$ and naltrexone $\mathrm{HCl}$ are depicted in Figure 1.

\subsection{Post Compression Parameters}

Thickness Test: In all cases, tablets of $10 \mathrm{~mm}$ diameter and thickness $(2 \pm 0.01 \mathrm{~mm})$ were produced.

Hardness Test: The surface hardness of each tablet is expressed in $\mathrm{N}$, in the range of 96.30-123.37 N.

The physical properties of the new formulations were considered, in all cases, acceptable.

\subsection{In Vitro Dissolution Studies}

The dissolution profiles of both BUP. $\mathrm{HCl}$ and NTX $\cdot \mathrm{HCl}$ are depicted in Figures 2 and 3, respectively.

The kinetic release properties of the developed formulations (B1-B7, N1-N7), Wellbutrin ${ }^{\circledR}$ XR 150 and $300 \mathrm{mg}$, are reported in Table 2. The terms $t_{20 \%}, t_{50 \%}$ and $t_{90 \%}$ refer to the time when $20 \%, 50 \%$ and $90 \%$, respectively, of the dissolution that has been achieved. D.E.\% refers to \% dissolution efficiency and $n$ denotes the release kinetics according to the power law. 
Table 2. Kinetic release properties of the developed formulations (B1-B7, N1-N7), Wellbutrin ${ }^{\circledR}$ XR 150 and 300 mg.

\begin{tabular}{|c|c|c|c|c|c|c|}
\hline Formulations & MDT & $t_{20 \%}$ & $t_{50 \%}$ & $t_{90 \%}$ & $n$ & Mean \% D.E. \\
\hline B1 & 98.86 & 37 & 284 & $*$ & 0.36 & 39.56 \\
\hline B2 & 129.50 & 65 & 350 & $*$ & 0.44 & 36.53 \\
\hline B3 & 194.58 & 138 & 210 & 399 & $* *$ & 51.97 \\
\hline B4 & 133.56 & 23 & 114 & 315 & 0.61 & 71.03 \\
\hline B5 & 145.93 & 32 & 137 & 393 & 0.61 & 62.81 \\
\hline B6 & 146.72 & 35 & 159 & $*$ & 0.66 & 55.76 \\
\hline B7 & 144.99 & 45 & 167 & * & 0.67 & 56.75 \\
\hline Wellbutrin ${ }^{\circledR}$ XR $150 \mathrm{mg}$ & 232.29 & 173 & 320 & * & 0.51 & 33.73 \\
\hline Wellbutrin ${ }^{\circledR}$ XR $300 \mathrm{mg}$ & 217.44 & 163 & 354 & $*$ & 0.75 & 31.74 \\
\hline N1 & 101.14 & 16 & 72 & 271 & 0.33 & 78.74 \\
\hline N2 & 78.93 & 13 & 70 & 269 & $* *$ & 83.67 \\
\hline N3 & 50.60 & 10 & 24 & 131 & $* *$ & 89.42 \\
\hline N4 & 124.16 & 16 & 98 & 342 & 0.31 & 72.21 \\
\hline N5 & 113.18 & 14 & 94 & 318 & 0.29 & 75.28 \\
\hline N6 & 169.97 & 46 & 283 & $*$ & 0.56 & 45.60 \\
\hline N7 & 130.82 & 15 & 118 & 346 & 0.39 & 70.23 \\
\hline
\end{tabular}

* The active pharmaceutical ingredient (API) did not reach 90\% release during the dissolution experiment. ** Not Applicable.

It is apparent from the data presented in Figure 2, that the \% release of $\mathrm{BUP} \cdot \mathrm{HCl}$ from formulations B1-B7, with the exception of B3 (marginally higher at $\mathrm{pH} 1.2$ ), was higher than that of the market drug, Wellbutrin $\mathrm{XR}^{\circledR} 150$ and 300, at both pHs (1.2 and 6.8).

Specifically, the \% release of BUP. $\mathrm{HCl}$ from formulation $\mathrm{B} 6$, which contained $\mathrm{PEO}$, was higher (41.29\%; pH 1.2) than that from formulation B3 (10.87\%; pH 1.2), which contained Eudragit ${ }^{\circledR}$ L100-55. An enhanced release of BUP. $\mathrm{HCl}$ from formulation B3 was noticed only at $\mathrm{pH}$ 6.8. Albeit the fact that, at this $\mathrm{pH}, \mathrm{BUP} \cdot \mathrm{HCl}$ was not protonated and thus its aqueous solubility was reduced, the presence of Eudragit ${ }^{\circledR}$ L100-55 (Scheme 2) permitted the facile water penetration into these tablets, at $\mathrm{pH} 6.8$, leading to an increased release of this API (B3: $89.63 \%$; B6: $84.73 \%$ at $480 \mathrm{~min}$ ) [42]. The \% release of BUP. $\mathrm{HCl}$ from formulations B4 and B5 was higher $(71.03 \%$ and $46.50 \%$, respectively) than that from formulation $\mathrm{B} 6(41.29 \%)$, at $\mathrm{pH}$ 1.2. At $\mathrm{pH}$ 6.8, the release of $\mathrm{BUP} \cdot \mathrm{HCl}$ from the tablets of formulation $\mathrm{B} 5$ resembles the release from formulation $\mathrm{B} 3$, at $300 \mathrm{~min}$ and thereafter.

The substitution of Eudragit ${ }^{\circledR}$ L100-55 (formulation B3) in the formulations B4 and B5, with PEO, especially from B4, which contained a higher amount of PEO (37.5\%), in comparison to B5 (24\%), led to an increase of the total \% drug release $(100 \%$ and $94.02 \%$, compared to $89.63 \%$ ). PEO (Scheme 2) is the most widely used excipient in controlled release matrix tablets, owing to its aqueous solubility, availability in a range of molecular weight/viscosity grades and unique swelling/erosion properties, which can be utilized in modulating drug release profiles [11,42].

The replacement of Eudragit ${ }^{\circledR}$ L100-55 (formulation B3) in formulations B1 and B2, with HPMC, especially in B1 that contained a higher amount of HPMC (37.5\%) in comparison to B2 (24\%), led to a noteworthy release of BUP. $\mathrm{HCl}$, at $\mathrm{pH} 1.2$ (B1: $35.98 \%$; $\mathrm{B} 2: 29.72 \%$, at $120 \mathrm{~min}$ ), and to a sustained release, thereafter (B1: $54.29 \%$; B2: $55.13 \%$, at $480 \mathrm{~min}$ ). It seems these HPMC K15M-based formulations were able to control the release of the drug to a higher extent than those containing Eudragit ${ }^{\circledR}$ and PEO based formulants. This could be attributed to the high viscosity and density of HPMC K15M (Scheme 2), which forms a rigid gel upon contact with the aqueous media, thus controlling the delivery of the highly water-soluble drug (BUP. $\mathrm{HCl}$ ) [45].

The drug release from the formulations B1 and B2 (that contained 37.5\% HPMC and $24 \%$ HPMC, respectively) showed a decrease in relation to the drug release from formulations B4 and B5 (that contained 37.5\% and 24\% PEO, accordingly) (D.E. $\%$ B1: 39.56, B2: 36.53 and B4: 71.03, B5: 62.81). In previous papers, the same trend was observed when HPMC K15M and PEO including tablets of BUP.HCl, were compared [46]. It has been adequately documented that in swellable matrices, the release of the drug is sustained by 
one or more of processes, including the diffusion of water into the matrix, the swelling, due to the hydration of matrix or the relaxation of polymer chains (often referred as Case II transport), a diffusion process of the drug, through the existing pores or erosion of the matrices [47-49]. The release rate of $\mathrm{BUP} \cdot \mathrm{HCl}$ was faster through the PEO containing matrices than that of HPMC K15M; this may be due to the overall erosion rate of PEO, which is faster than that of HPMC K15M.<smiles>CCOC(=O)CCC(C)(CC(C)(C)C)C(=O)O</smiles>

(a)

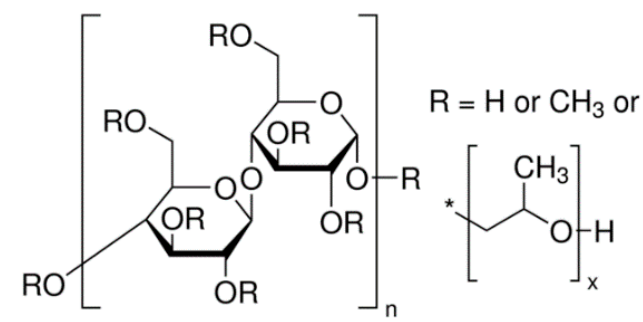

(c)<smiles>CC(O)CCOC(C)C</smiles>

(b)

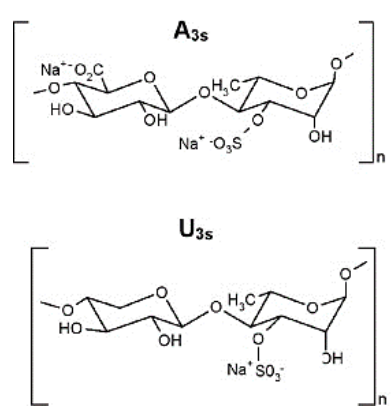

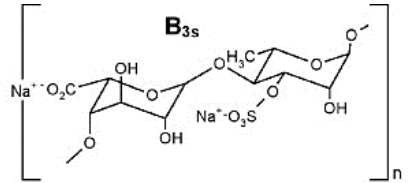

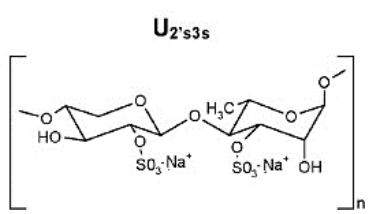

(d)

Scheme 2. Chemical structure of: (a) Eudragit ${ }^{\circledR}$ L100-55, (b) poly(ethylene oxide) (PEO), (c) hydroxypropylmethycellulose (HPMC K15M) and (d) structure of the main repeating disaccharides in Ulva ulvan: ulvanobiuronic acids $\mathrm{A}_{3 S}$ and $\mathrm{B}_{3 S}$ and ulvanobioses $U_{3 S}$ and $U_{2^{\prime} S, 3 S}[29]$.

The drug release from the formulations B5, B4 and B6, which contained $24 \%, 37.5 \%$ and 61.5\% PEO, respectively (D.E.\% B5: 62.81, B4: 71.03 and B6: 55.76) showed a decrease when the $\%$ PEO was increased. In previous reports, the same trend was observed; the decrease in drug release with increasing PEO content may be attributed to the increased viscosity of the gel layer, as well as, the formation of a gel layer with a thicker diffusional layer [50-53].

The tablets containing ulvan (24\%) (formulation B7), showed a relatively higher drug release (B7: $38.08 \%$, at $120 \mathrm{~min}$ and $84.21 \%$ at $480 \mathrm{~min}$ ) than that of the market drugs (Wellbutrin ${ }^{\circledR}$ XR 150: $2.35 \%$ at $120 \mathrm{~min}$ and $75.09 \%$ at $480 \mathrm{~min}$; Wellbutrin ${ }^{\circledR}$ XR 300: $2.62 \%$ at $120 \mathrm{~min}$ and $66.85 \%$ at $480 \mathrm{~min}$ ) which contained polyvinylalcohol and glyceryl dibehenate inside the tablets and ethylcellulose, polyethylenoglycol 1450, Povidon K90, methacrylic acid, ethyl acrylate copolymer dispersion (Eudragit ${ }^{\circledR}$ L30 D-55), silicon dioxide and triethyl citrate, as a coating. Ulvan, conversely to the commonly used algae, sodium alginate, has an unusual chemical composition, and a regular structure combining. The marine product, used in the present study, was highly sulphated and contained rhamnose 3-sulphate, xylose, xylose 2-sulphate, glucuronic acid and iduronic acid residues. Thus, in the acidic environment, a number of ulvan's functionalities remained charged, facilitating that way the dissolution of BUP. $\mathrm{HCl}$ (approximately 38\%). It is interesting to note that at $\mathrm{pH}$ 6.8 , this dissolution enhancing effect of ulvan was maintained. BUP. $\mathrm{HCl}$ reached an $84.21 \%$ release from tablets containing ulvan (B7) at $8 \mathrm{~h}$. At this $\mathrm{pH}$, all the sulfate and carboxylate groups of ulvan were ionized, thus facilitating the BUP's release. Apart from the $\mathrm{pH}$ value and the functionalities of ulvan, which affected the dissolution of bupropion, the amorphous shape and size of ulvans [54], also contributed to BUP's enhanced release. Moreover, ulvan's particles have a sponge-like shape with large cavities through which the molecules of the aqueous medium penetrate faster and deeper [Scheme 2]. 
The kinetics release data, obtained via the Korsmeyer-Peppas equation (Table 2), revealed that the release of $\mathrm{BUP} \cdot \mathrm{HCl}$, from the formulations tested, followed in most cases (B4 $(n=0.61), \mathrm{B} 5(n=0.61), \mathrm{B} 6(n=0.66), \mathrm{B} 7(n=0.67)$ Wellbutrin ${ }^{\circledR}$ XR $150 \mathrm{mg}(n=0.51)$ and Wellbutrin ${ }^{\circledR}$ XR $\left.300 \mathrm{mg}(n=0.75)\right)$, a non-Fickian pattern $(0.45<n<0.89$, anomalous diffusion), i.e., a combined mechanism of pure diffusion and Case II transport [55].

Factors $\mathrm{f} 1$ and $\mathrm{f} 2$ were calculated, by using the respective equations, and showed that apart from formulation B3, which contained Eudragit ${ }^{\circledR}$ L100-55, all the other formulations differed from those calculated for Wellbutrin ${ }^{\circledR}$ XR (150 mg and $300 \mathrm{mg}$ ) (Table S1, Supplementary Materials); this was in agreement with the release data presented above. These results were also corroborated by the ANOVA tests (Tables S2 and S3 in Supplementary Materials) on the respective D.Es.\%.

The dissolution curves of NTX.HCl (N1-N7) from the matrix tablets at both pHs $(1.2$ and 6.8) are depicted in Figure 3. In detail, the \% release of $\mathrm{NTX} \cdot \mathrm{HCl}$ from formulation N6, which contained PEO (95\%), was lower (77.90\%) than that from formulation N3 (100\%), involving Eudragit ${ }^{\circledR}$ L100-55 (95\%), at both pHs, 1.2 and 6.8. This finding, which was the opposite of the that noticed in the respective formulation of BUP. $\mathrm{HCl}$, could be attributed to the fact that BUP. $\mathrm{HCl}$, albeit being a much more water-soluble compound (solubility: $312 \mathrm{mg} / \mathrm{mL}$ ) [5,56] than NTX.HCl (solubility: $100 \mathrm{mg} / \mathrm{mL}$ ) [57], was used in a much higher quantity $(37.5 \%)$, in all formulations tested, than $\mathrm{NTX} \cdot \mathrm{HCl}(4 \%)$. The same trend was noticed and at $\mathrm{pH}$ 6.8. This was expected, as the much higher quantity of Eudragit ${ }^{\circledR}$ L100-55 in all NTX.HCl formulations, lead to an enhancement of its release, because in the formulation N3, which involved the $\mathrm{pH}$ dependent, water soluble polymer, Eudragit ${ }^{\circledR}$ L100-55, a facile water penetration into the tablet was permitted and consequently the hydration of the formulation system, leading to a sustained drug dissolution profile [58].

However, the \% release of NTX from formulations N4 (Eudragit ${ }^{\circledR}$ L100-55 37\%; PEO 58\%) and N5 (Eudragit ${ }^{\circledR}$ L100-55 58\%; PEO 37\%) was higher (100\% release in both cases) than that from formulation N6 (PEO 95\%) $(77.90 \%)$, at both pH's. The release from the formulation $\mathrm{N} 4$ resembled the release from formulation N5 (D.E.\% N4: 72.21 and N5: 75.28). The substitution of Eudragit ${ }^{\circledR}$ L100-55 (formulation N3) in formulations N4 and N5, with PEO, especially N4 that contained a higher amount of PEO (58\%) in comparison with N5 (37\%), lowered the total \% drug release. As previously mentioned, PEOs are swellable polymers, capable of forming strong hydrogen bonds with the water molecules, resulting to high water uptake and modified release [42].

The replacement of Eudragit ${ }^{\circledR}$ L100-55 (formulation N3) in formulations N1 and N2 with HPMC K15M, especially N1, which contained a higher amount of HPMC K15M (58\%) in comparison with N2 (37\%), lowered the total \% drug release (D.E.\% N1: 78.74 and N2: 83.67). It seemed these HPMC K15M-based formulations were able to control the release of the drug to a higher extent than those containing the Eudragit ${ }^{\circledR}$ and PEO formulants. This could be attributed to the high viscosity and density of HPMC K15M, leading to a rigid gel formation, upon contact with the aqueous media, thus controlling the delivery of the sparingly water-soluble drug $(\mathrm{NTX} \cdot \mathrm{HCl})$ [45].

The drug release from the formulations N1 and N2 (containing 58\% HPMC and $37 \%$ HPMC, respectively) showed a small increase in relation to the drug release from formulations N4 and N5 (58\% and 37\% PEO, respectively) (D.E.\% N1: 78.74, N2: 83.67 and N4: 72.21, N5: 75.28). This was in agreement with the findings, reported in US 8,916,195B2 patent, on HPMC and PEO involving NTX tablets [59].

The tablets containing ulvan (37\%) (formulation N7), showed a relatively higher drug release (N7: $52.80 \%$, at $120 \mathrm{~min}$ and $98.97 \%$ at $480 \mathrm{~min}$; D.E.\%: 70.23), when compared with N6 (N6: 31.39\%, at $120 \mathrm{~min}$ and 77.90\% at $480 \mathrm{~min}$; and D.E.\%: 45.60). At pH 1.2, the sulfate groups of ulvan remain uncharged, conversely to its carboxylate groups. This partial ionization of ulvan leaded to an enhancement of NTX release from the N7 tablets, compared to the non-ulvan containing tablets N6.

It was interesting to note that at $\mathrm{pH}$ 6.8, this dissolution enhancing effect of ulvan was maintained. At this $\mathrm{pH}$, apart from the sulfate groups of ulvan, its carboxylates are 
also present in the ionized form, and this led to an enhanced NTX release from the N7 formulations. The substitution of Eudragit ${ }^{\circledR}$ (formulation N4) in formulation N7 (D.E.\% N4: 72.21 and N7: 70.23) with ulvan slightly lowered the \% drug release.

The kinetics release data, obtained via the Korsmeyer-Peppas equation (Table II), revealed that the release of NTX from the formulations studied, followed in the cases of N6 ( $n$ : 0.56) a non-Fickian pattern $(0.45<n<0.89$, anomalous diffusion), i.e., a combined mechanism of pure diffusion and Case II transport [55], whilst in the case of N7 ( $n: 0.39$ ), which included the ulvan polymer, it approached the Fickian pattern.

\subsection{Polymer Erosion Studies}

The erosion profiles of both BUP. $\mathrm{HCl}$ and NTX. $\mathrm{HCl}$ are depicted in Figures 4 and 5, respectively.

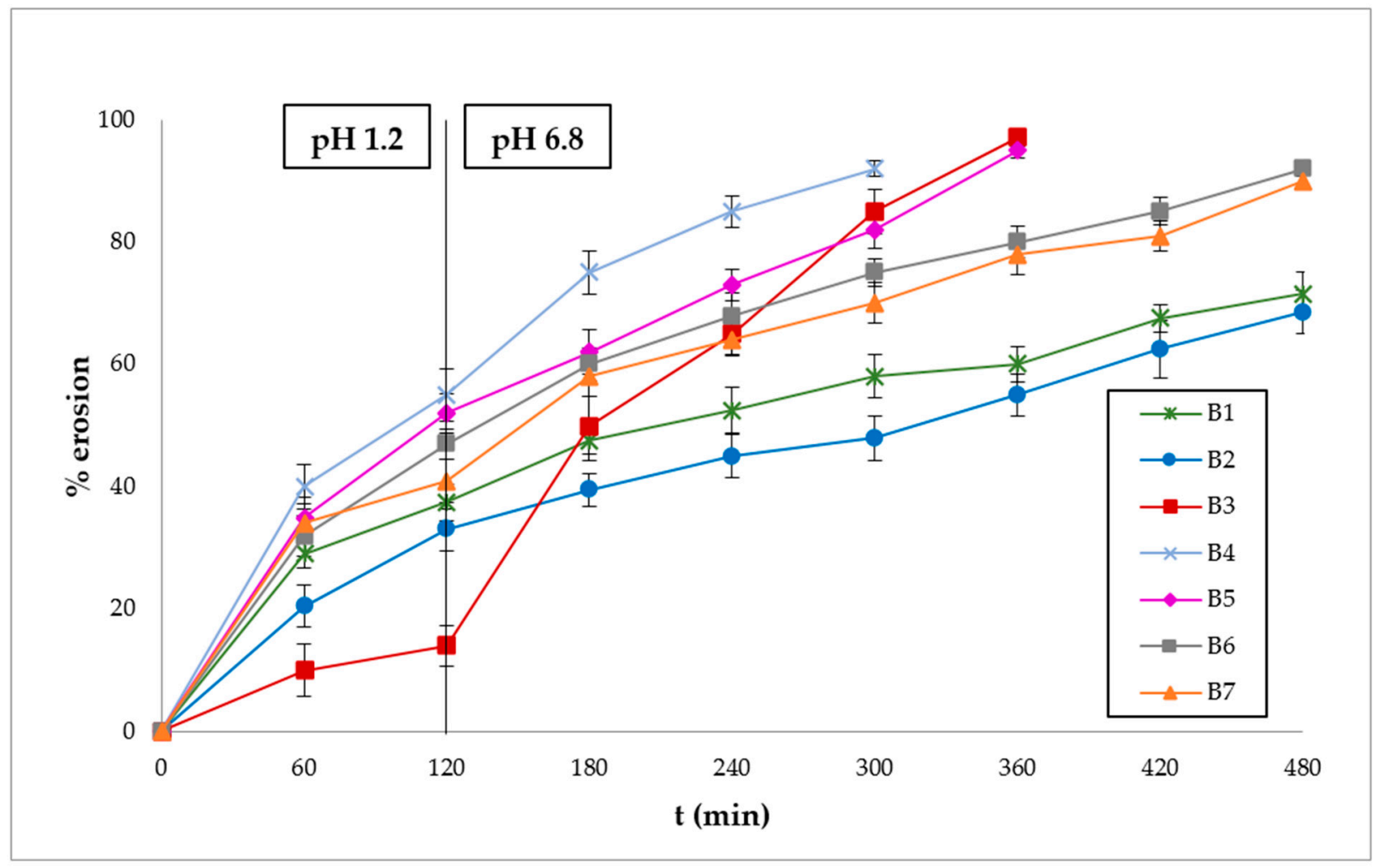

Figure 4. \% Erosion of BUP. $\mathrm{HCl}$ tablets formulations vs. time at $\mathrm{pH} 1.2(0-120 \mathrm{~min})$ and at $\mathrm{pH} 6.8$ (120-480 min). The results denote the mean value $(n=6)$.

Optical observation of B1 and B2 tablet formulations (containing 37.5\% and 24\% HPMC, respectively) during the dissolution and erosion experiments showed an increase of the gel network that delayed the water penetration into the glassy core [60]. Therefore, it could be assumed that the mechanism of these matrix systems was controlled by diffusion rather than erosion [61]; this was in agreement with the kinetics release figures shown in Table 2. On the other hand, the mechanism of erosion was dominant in B3 formulation containing Eudragit $^{\circledR}(61.5 \%)$, especially at $\mathrm{pH}=6.8$. As previously mentioned, Eudragit ${ }^{\circledR}$ L100-55 is a $\mathrm{pH}$ dependable multifunctional polymer, which is soluble at $\mathrm{pH}>5.5$ [62]. During the dissolution and erosion studies, it was observed that the B3 matrix tablets started to form a thick gel layer in acidic environment $(\mathrm{pH}=1.2)$, which was followed by an abrupt matrix erosion in the neutral environment $(\mathrm{pH}=6.8)$. Consequently, after the first $2 \mathrm{~h}$ of dissolution, a maximum release of the drug occurred, with a simultaneous total erosion of the tablets [63,64]. Formulations B4, B5 and B6 (containing 37.5\%, 24\% and 61.5\% PEO, respectively) were characterized by a diffusion-based mechanism [65]. Ulvan and PEO combination matrix tablets (B7) were characterized also by a Fickian diffusion drug re- 
lease. Both polymers created a cross-link network that entangled BUP, thus controlling its release [24].

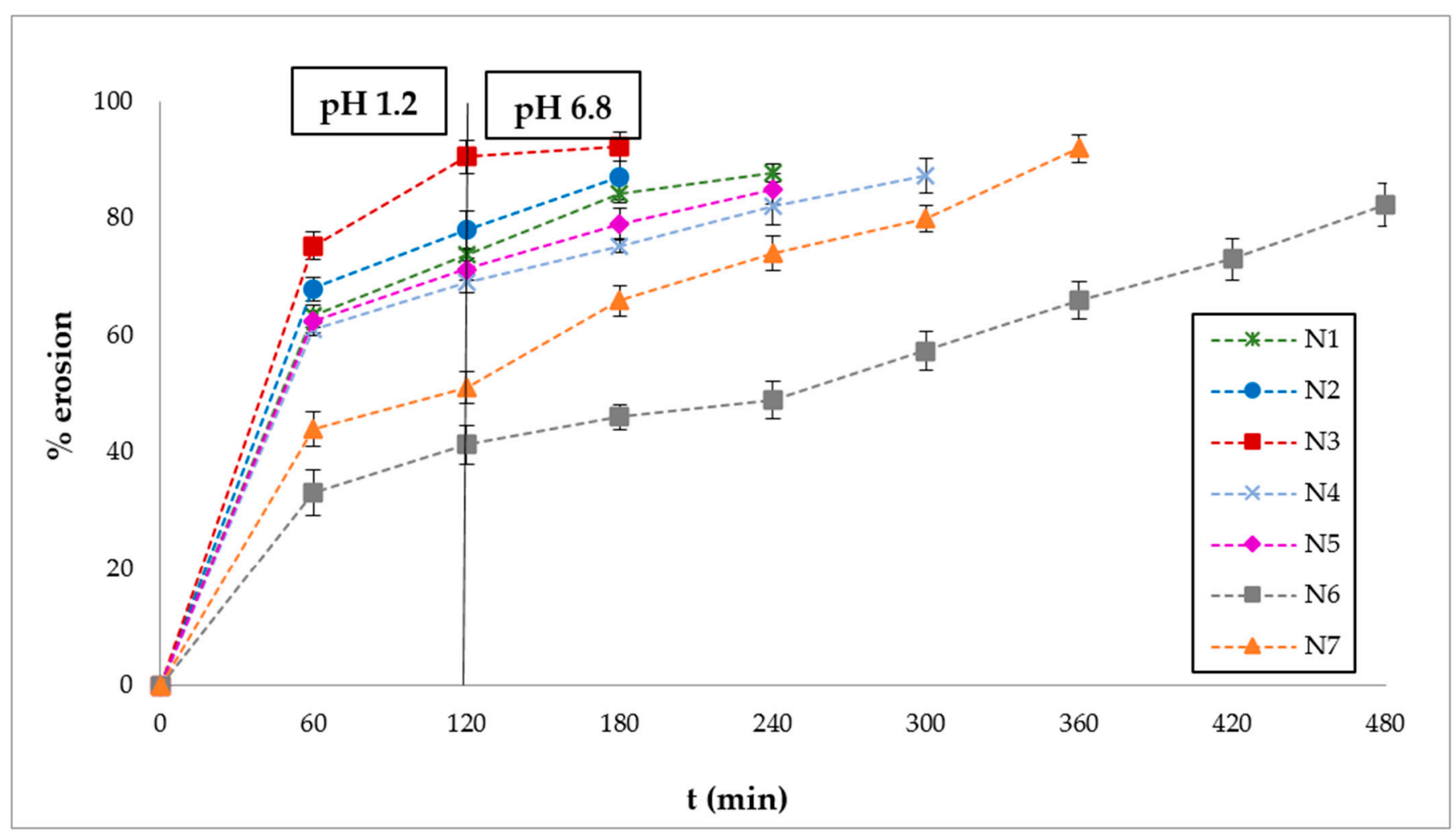

Figure 5. \% Erosion of NTX. $\mathrm{HCl}$ tablets formulations vs. time at $\mathrm{pH} 1.2(0-120 \mathrm{~min})$ and at $\mathrm{pH} 6.8(120-480 \mathrm{~min})$. The results denote the mean value $(n=6)$.

Erosion studies on NTX tablet formulations N1 and N2 (which contained 58\% and $37 \%$ HPMC, respectively) showed that HPMC augmented the swelling front of the tablets and delayed the water diffusion into the glassy core (optical observation) [60]. According to their kinetic profile (Korsmeyer-Peppas model), the mechanism of these matrix systems, was controlled by diffusion rather than erosion, id est that polymer chain relaxation was dominant comparatively to molecular diffusion [61]. Moreover, the hydration and erosion rate of $\mathrm{N} 1$ and $\mathrm{N} 2$ formulations was determined by the polymer combination used. In specific, in N1, which contained a higher amount of HPMC, it was initially observed a thicker gel layer than in N2, which, conversely, consisted of a higher amount of Eudragit ${ }^{\circledR}$ leading to faster erosion [66]. Formulations N4 and N5 (58\% and 37\% PEO, respectively) showed a similarity in dissolution and consequently in the erosion profile. PEO when used in combination with Eudragit ${ }^{\circledR}$ L100-55 produced a hydrogel layer, contributing mainly to a diffusional than erosive mechanism [67], which corresponded to a Fickian diffusion. Eudragit ${ }^{\circledR}$ enhanced the erosion of the matrix, compared to N6 (95\% PEO), contributing to a higher drug release. Drug release was characterized by a diffusion-based mechanism when PEO was used in a maximum quantity in formulation N6 (95\%). For the first two hours, as the tablets remained in the acidic environment $(\mathrm{pH}=1.2)$ a gel layer started forming, since PEO is a water-soluble excipient. After $4 \mathrm{~h}$ of dissolution and when the $\mathrm{pH}$ of the media was changed to neutral $(\mathrm{pH}=6.8)$, the swelling and erosion front was in a synchronization, concomitantly conducting in a progressive erosion until the end of the dissolution experiment $[65,68]$. Matrix tablets N7 consisted of a PEO and ulvan combination; in this case the drug content was released in a Fickian pattern. Ulvan is characterized by a great capability of water solubility and jellification, physicochemical properties that are critical in the diffusional mechanism of the swelling matrix. In this 
matrix system combination, not only PEO, but also ulvan, created a cross-link network of polymers that entrapped the API and controlled its release in an extended way, leading after $8 \mathrm{~h}$ to complete erosion [24].

\section{Discussion}

Both bupropion and naltrexone have a pharmacological potential in the nervous system. Bupropion stimulates hypothalamic pro-opiomelanocortin (POMC) neurons' activity, secreting $\alpha$-melanocyte-stimulating hormone $(\alpha-\mathrm{MSH})$, which is related with lower energy intake and food craving. On the other hand, naltrexone acts in a synergistical way with bupropion by blocking $\mu$-opioid receptors on POMC neurons resulting to a reduced release of $\alpha$-MSH [69]. The efficacy of this combination treatment is examined by four clinical trials that are in phase three, named as CONTRAVE Obesity Research (COR), which use a modified intent-to-treat (ITT) analysis as well as attrition (COR-1,4 COR-II,5 COR-BMOD6 and COR-Diabetes) [70]. As shown in these four clinical trials naltrexone/bupropion combination has a great efficacy for the treatment of obesity, as it provides a better patient's safety profile, in contrast with other medications (e.g., phentermine/topiramate), its use is well tolerated with common adverse effects and no abuse phenomena are provoked $[69,71]$.

Moreover, the pharmacological and pharmacokinetic profiles of the two APIs were examined in order to ameliorate and to develop pharmaceutical forms simulating the commercially available $[72,73]$. As far as $\mathrm{BUP} \cdot \mathrm{HCl}$ is concerned, available cytotoxicity data have shown that less than $10 \mathrm{~g}$ are considered toxic [74] and the optimum dosage for extended release is 150 to $450 \mathrm{mg}$ /day [72]. According to these data, the dosage used, was selected to be $75 \mathrm{mg}$ (half of Wellbutrin ${ }^{\circledR} \mathrm{XR} 150 \mathrm{mg}$ ), as $75 \mathrm{mg}$ is considered initiative to therapy [3]. In addition, NTX. $\mathrm{HCl}$ toxicity studies have shown that generally $\geq 1000 \mathrm{mg} / \mathrm{kg}$ can provoke mortalities and the optimum dosage is adjusted from 25 to $50 \mathrm{mg}$, depending on the stage of treatment [75]. However, in the present study, the therapeutic dosage was selected to be $8 \mathrm{mg}$, as it is considered effective in managing obesity, when used in combination with $\mathrm{BUP} \cdot \mathrm{HCl}[76]$.

The design of the aforementioned formulations was based on literature reports, which examine the properties of excipients in sustained release formulations. The properties of each excipient and the APIs, such as physicochemical properties (solubility, polymorphic structures, etc.), are also included for a more comprehensive and complete perception of the formulation design (Figure 6) [77]. Furthermore, it is well documented, and reported in the experimental analysis, that the utilized excipients are pharmacologically inactive and do not present any incompatible properties to those of the APIs, when formulated in matrix-type tablets $[33,47]$.

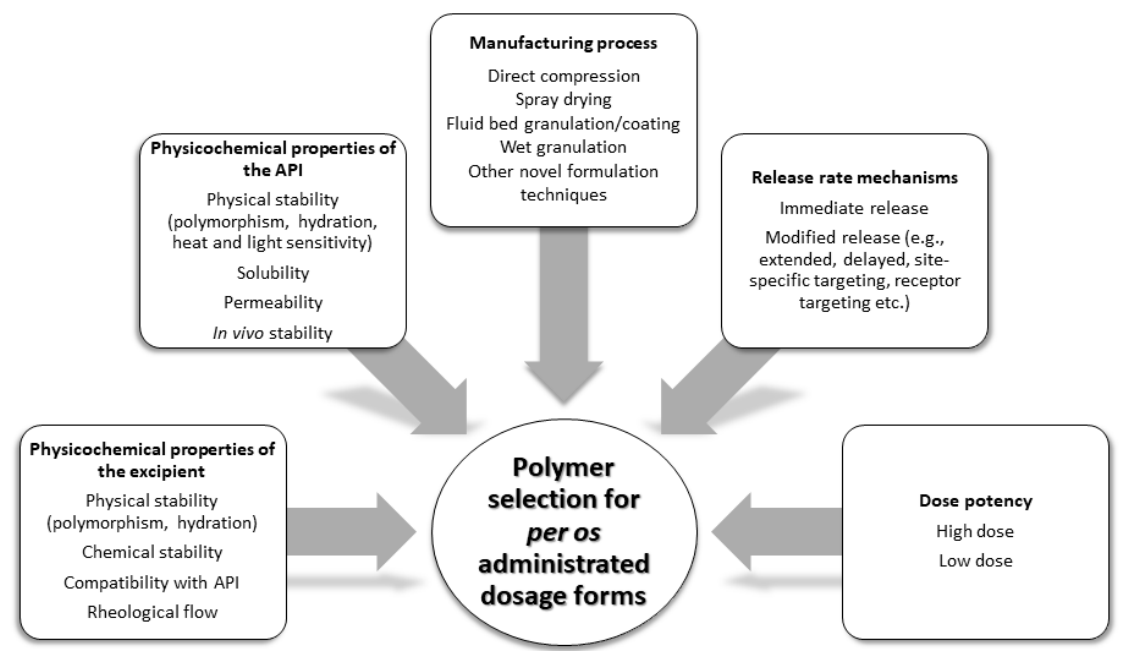

Figure 6. Parameters that are essential on selecting polymers for per os administrative dosage forms. 
The choice of excipients is based in several drug release and erosion studies that have shown a well-functionality and efficacious properties of the used polymers. These polymerbased drug delivery systems appeared to be depended by diffusion or erosion mechanisms, solvent activation (swelling or osmotically controlled) or stimulated by external factors (e.g., pH, temperature or sink conditions) $[11,19,78]$ Moreover, an Ishikawa diagram or a "cause and effect diagram" (Figure 7), depicts concisely a lab scale manufacturing process, showing the most crucial factors and parameters, which contribute in the initial design and development of sustained release rate matrix-based oral drug delivery systems of $\mathrm{BUP} \cdot \mathrm{HCl}$ and NTX.HCl. Parameters such as materials, methods, instruments, measurements, personnel and environment are considered significant for the formulation process optimization [79].

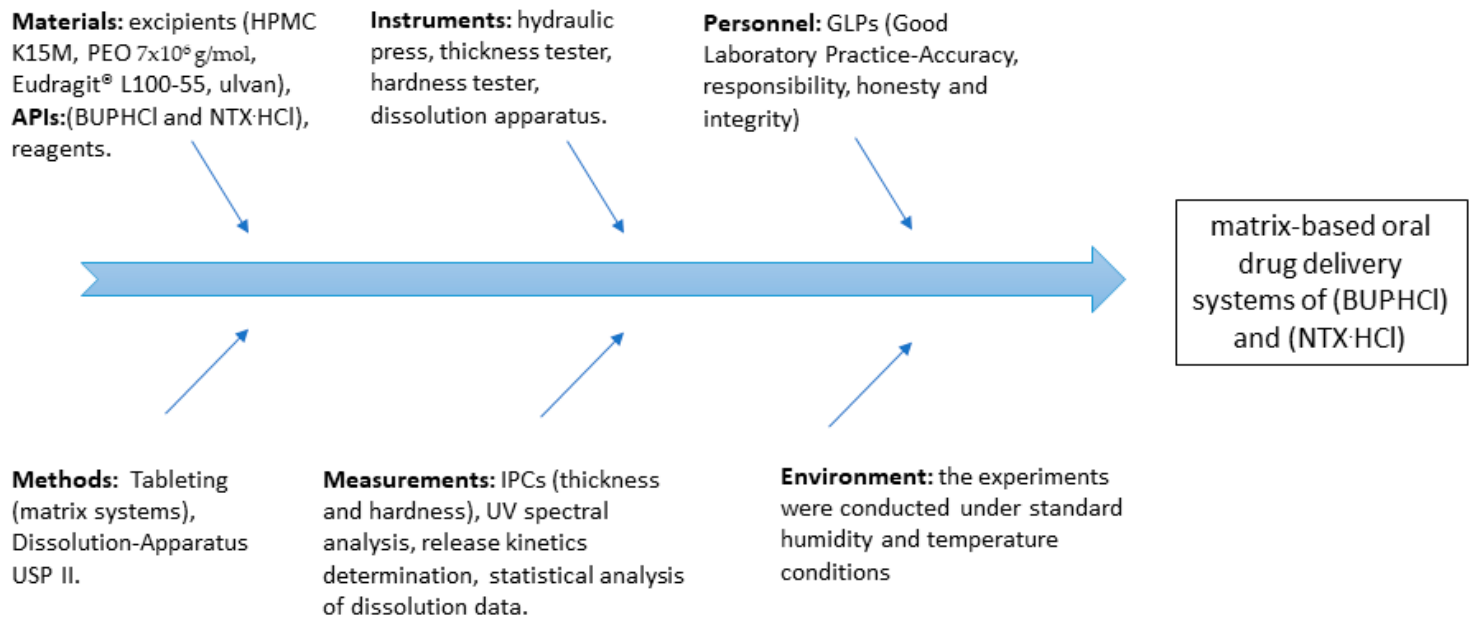

Figure 7. Ishikawa diagram: parameters that are crucial for the design and the development of matrix-based oral drug delivery systems of BUP. $\mathrm{HCl}$ and $\mathrm{NTX} \cdot \mathrm{HCl}$.

Eudragit ${ }^{\circledR}$ L100-55 is a soluble and $\mathrm{pH}$ dependable polymer, due to its ionized side group. It is characterized as a useful excipient in flavor masking and in coating (preventing moisture and light degradation of the API) [80]. Its use is very common when designing tablet formulations for targeted gastrointestinal delivery. In specific, Eudragit ${ }^{\circledR}$ L100-55 is not soluble at acidic $\mathrm{pH}$ environments; however, it dissolves at $\mathrm{pH}>5.5$ in the small intestine [62]. Eudragit ${ }^{\circledR}$ L100-55 enhances the release of BUP. $\mathrm{HCl}$ at $\mathrm{pH}$ 6.8. Additional studies indicated that the use of this polymer promotes an erosion mechanism of release at neutral $\mathrm{pH}$. However, when Eudragit ${ }^{\circledR} \mathrm{L} 100-55$ is used in $\mathrm{NTX} \cdot \mathrm{HCl}$ formulations, a higher release of the active substance is observed in timepoints, which correspond to acidic conditions. This is assignable to the use of a large amount of Eudragit ${ }^{\circledR}$ L100-55, in association with its water solubility properties, resulting in augmented water penetration in the matrix [58].

Another polymer, which is widely used in pharmaceutics, is PEO; it is characterized as a tablet binder, when used at concentrations of $5-85 \%$ and has excellent mucoadhesive properties. Moreover, polyethylene oxides of high molecular weight grades provide a delayed drug release via the hydrophilic matrix approach [81-83]. This polymer can form strong hydrogen bonds with water molecules thus leading to high water uptake and formation of a gel layer. In this report, its unique swelling/erosion properties were utilized in order to modify the release profiles of the two APIs. The use of PEO led to a decreased drug release, which could be due to the formation of a viscous gel layer. Erosion studies indicated a Fickian diffusion-based drug release mechanism.

One more water-soluble polymer is HPMC. It shows more extensive swelling properties and a steady rate of erosion of the polymeric matrix, after contact with gastrointestinal fluids, due to its slow water intake and small porosity characteristics. In particular, it is widely used in controlled release systems in order to provide a gradual, slow and extensive release rate of the active substance from the dosage form [84]. In this report, 
the HPMC K15M-based formulations were found effective in controlling the release of the highly water-soluble drug (BUP. $\mathrm{HCl})$ and the sparingly water-soluble drug $(\mathrm{NTX} \cdot \mathrm{HCl})$, due to rigid gel formation. When HPMC is used, as an excipient in these formulations, the mechanism of drug release is controlled by diffusion rather than erosion.

Ulvans are polysaccharides, which can be used in matrix monolithic systems, in order to provide a controlled release rate of the API, due to gel formation [85]. This property renders it a suitable excipient for exploiting its use in per os administered solid dosage forms. The results of our study revealed that when used in the produced tablets, this natural biopolymer created a hydrogel layer, which surrounded the formulations and allowed a slow and prolonged release of the APIs through the matrix.

\section{Conclusions}

Aiming at avoiding burst release of bupropion hydrochloride, and especially naltrexone hydrochloride, from oral tablets, and to concurrently achieve their controlled initial release, new formulations of these two drugs were prepared. The use of these modified release formulations, employing HPMC K15M, Eudragit ${ }^{\circledR}$ L100-55, PEO $\left(7 \times 10^{6}\right)$ and ulvan, as the rate controlling polymers, resulted in the relatively low release of these drugs, at $0 \leq \mathrm{t} \leq 120 \mathrm{~min}$. Under in vivo conditions this could possibly prove to aid the elimination of the peaks associated with daily drug administration, while maintaining continuous therapeutic levels for an extended time frame. This could decrease the possibility of appearance of adverse events, associated with peaks, and improve efficacy by avoiding drug concentration dunking. We are currently involved with the design and preparation of compounded bupropion hydrochloride and naltrexone hydrochloride tablets, en route to our future task to develop new oral formulations capable of confronting the obesity menace.

Supplementary Materials: The following are available online at https: / www.mdpi.com/article / 10.3390 / polym13091456/s1, Table S1: title $\mathrm{f}_{1}$ and $\mathrm{f}_{2}$ indices of the developed formulations (B1-B7, N1-N7), Wellbutrin ${ }^{\circledR}$ XR 150 and $300 \mathrm{mg}$; Table S2: ANOVA results of the developed formulations (B1-B7), Wellbutrin $\mathrm{XR}^{\circledR} 150$ and $300 \mathrm{mg}$; Table S3: ANOVA results of the developed formulations (N1-N7).

Author Contributions: Conceptualization, M.V.; methodology, M.V and A.S.; investigation, A.S and A.D.; resources, M.V.; data curation, A.S. and A.D.; writing-original draft preparation, M.V. and A.S.; writing-review and editing, M.V.; supervision, M.V. All authors have read and agreed to the published version of the manuscript.

Funding: This research received no external funding.

Institutional Review Board Statement: Not applicable.

Informed Consent Statement: Not applicable.

Acknowledgments: The authors would like to extend their gratitude to T. Papasandas Pharmacy for providing Wellbutrin $\mathrm{XR}^{\circledR} 150$ and $300 \mathrm{mg}$ tablets.

Conflicts of Interest: The authors declare no conflict of interest.

\section{References}

1. Connarn, J.N.; Flowers, S.; Kelly, M.; Luo, R.; Ward, K.M.; Harrington, G.; Moncion, I.; Kamali, M.; Mcinnis, M.; Feng, M.R.; et al. Pharmacokinetics and pharmacogenomics of bupropion in three different formulations with different release kinetics in healthy human volunteers. AAPS J. 2017, 19, 1513-1522. [CrossRef]

2. Muralidhar, P.; Bhargav, E.; Srinath, B. Formulation and optimization of bupropion $\mathrm{HCl}$ microsponges by 23 factorial design. Int. J. Pharm. Sci. Res. 2017, 8, 1134-1144. [CrossRef]

3. Foley, K.F.; De Santy, K.P.; Kast, R.E. Bupropion: Pharmacology and therapeutic applications. Expert Rev. Neurother. 2006, 6, 1249-1265. [CrossRef]

4. Maccaroni, E.; Malpezzi, L.; Famulari, A.; Masciocchi, N. Structural and energetic aspects of a new bupropion hydrochloride polymorph. J. Pharm. Biomed. Anal. 2012, 60, 65-70. [CrossRef]

5. Khan, S.R.; Berendt, R.T.; Ellison, C.D.; Ciavarella, A.B. Bupropion Hydrochloride. Profiles Drug Subst. Excip. Relat. Methodol. 2016, 41, 1-30. [CrossRef] 
6. Hollingsworth, E.B.; Kenney, B.T. Synthesis and Evaluation of the Antidepressant Activity of the Enantiomers of Bupropion. Chirality 1993, 5, 495-500. [CrossRef]

7. Dwoskin, L.P.; Rauhut, A.S.; King-Pospisil, K.A.; Bardo, M.T. Review of the Pharmacology and Clinical Profile of Bupropion, an Antidepressant and Tobacco Use Cessation Agent. CNS Drug Rev. 2006, 12, 178-207. [CrossRef]

8. Patel, K.; Allen, S.; Haque, M.N.; Angelescu, I.; Baumeister, D.; Tracy, D.K. Bupropion: A systematic review and meta-analysis of effectiveness as an antidepressant. Ther. Adv. Psychopharmacol. 2016, 6, 1-46. [CrossRef]

9. Fava, M.; Rush, A.J.; Thase, M.E.; Clayton, A.; Stahl, S.M.; Pradko, J.F.; Johnston, J.A. 15 Years of Clinical Experience With Bupropion HCl: From Bupropion to Bupropion SR to Bupropion XL. J. Clin. Psychiatry 2005, 7, 106-113. [CrossRef]

10. Damaj, M.I.; Carroll, F.I.; Eaton, J.B.; Navarro, H.A.; Blough, B.E.; Mirza, S.; Lukas, R.J.; Martin, B.R. Enantioselective Effects of Hydroxy Metabolites of Bupropion on Behavior and on Function of Monoamine Transporters and Nicotinic Receptors. Mol. Pharmacol. 2004, 66, 675-682. [CrossRef]

11. Cha, K.-H.; Lee, N.; Kim, M.-S.; Kim, J.-S.; Park, H.J.; Park, J.; Cho, W.; Hwang, S.-J. Development and Optimization of a Novel Sustained-release Tablet Formulation for Bupropion Hydrochloride using Box-Behnken Design. J. Pharm. Investig. 2010, 40, 313-319. [CrossRef]

12. Settle, E.C. Bupropion sustained release: Side effect profile. J. Clin. Psychiatry 1998, 59, 32-36. [PubMed]

13. Jefferson, J.W.; Pradko, J.F.; Muir, K.T. Bupropion for major depressive disorder: Pharmacokinetic and formulation considerations. Clin. Ther. 2005, 27, 1685-1695. [CrossRef] [PubMed]

14. Blumberg, H.; Dayton, H.B. Naloxone, naltrexone and related noroxymorphones. Adv. in Biochem. Psychopharmacol. 1974, 8, 33-43.

15. Caraballo, I.; Melgoza, L.M.; Alvarez-Fuentes, J.; Soriano, M.C.; Rabasco, A.M. Design of controlled release inert matrices of naltrexone hydrochloride based on percolation concepts. Int. J. Pharm. 1999, 181, 23-30. [CrossRef]

16. Akala, E.O.; Wiriyacoonkasem, P.; Pan, G. Studies on in vitro availability, degradation, and thermal properties of naltrexone-loaded biodegradable microspheres. Drug Dev. Ind. Pharm. 2011, 37, 673-684. [CrossRef] [PubMed]

17. Fuller, B.E.; Rieckmann, T.; McCarty, D.; Smith, K.W.; Levine, H. Adoption of naltrexone to treat alcohol dependence. J. Subst. Abuse Treat. 2005, 28, 273-280. [CrossRef]

18. Kirchmayer, U.; Davoli, M.; Verster, A. Naltrexone maintenance treatment for opioid dependence. The Cochrane Library 2003, 2,1-17. [CrossRef]

19. Goonoo, N.; Bhaw-Luximon, A.; Ujoodha, R.; Jhugroo, A.; Hulse, G.K.; Jhurry, D. Naltrexone: A review of existing sustained drug delivery systems and emerging nano-based systems. J. Control. Release 2014, 183, 154-166. [CrossRef]

20. Meyer, M.C.; Straughn, A.B.; Lo, M.W.; Schary, W.L.; Whitney, C.C. Bioequivalence, dose-proportionality, and pharmacokinetics of naltrexone after oral administration. J. Clin. Psychiatry 1984, 45, 15-19.

21. Ornellas, T.; Chavez, B. Naltrexone SR/bupropion SR (Contrave): A new approach to weight loss in obese adults. P $\mathcal{E} T$ 2011, $36,255-362$.

22. Swinyard, E.A. Analgesic and Antipyretics. In Remington's Pharmaceutical Sciences, 18th ed.; Mack Publishing Company: Northampton, Pennsylvania, PA, USA, 1990; p. 1107.

23. Majee, S.B.; Avlani, D.; Biswas, G.R. Pharmacological, pharmaceutical, cosmetic and diagnostic applications of sulfated polysaccharides from marine algae and bacteria. Afr. J. Pharm. Pharmacol. 2017, 11, 68-77. [CrossRef]

24. Cardoso, M.J.; Costa, R.R.; Mano, J.F. Marine origin polysaccharides in drug delivery systems. Mar. Drugs 2016, 14, 34. [CrossRef]

25. Thirumurugan, G.; Dhanaraju, M.D. Marine Polysaccharides as Multifunctional Marine Polysaccharides as Multifunctional Pharmaceutical Excipients Pharmaceutical Excipients. Biol. Act. Appl. Mar. Polysacch. 2017, 129-143. [CrossRef]

26. Tziveleka, L.A.; Ioannou, E.; Roussis, V. Ulvan, a bioactive marine sulphated polysaccharide as a key constituent of hybrid biomaterials: A review. Carbohydr. Polym. 2019, 218, 355-370. [CrossRef] [PubMed]

27. Zhong, H.; Gao, X.; Cheng, C.; Liu, C.; Wang, Q.; Han, X. The Structural Characteristics of Seaweed Polysaccharides and Their Application in Gel Drug Delivery Systems. Mar. Drugs 2020, 18, 658. [CrossRef] [PubMed]

28. Robic, A.; Gaillard, C.; Sassi, J.F.; Lerat, Y.; Lahaye, M. Ultrastructure of ulvan: A polysaccharide from green seaweeds. Biopolymers 2009, 91, 652-664. [CrossRef] [PubMed]

29. Lahaye, M.; Robic, A. Structure and Functional Properties of Ulvan, a Polysaccharide from Green Seaweeds. Biomacromolecules 2007, 8, 1765-1774. [CrossRef]

30. Vlachou, M.; Kikionis, S.; Siamidi, A.; Tragou, K.; Ioannou, E.; Roussis, V.; Tsotinis, A. Modified in vitro release of melatonin loaded in nanofibrous electrospun mats incorporated into mono-layered and three-layered tablets. J. Pharm. Sci. 2019, 108, 970-976. [CrossRef]

31. Abdul, S.; Poddar, S.S. A flexible technology for modified release of drugs: Multi layered tablets. J. Control Release 2004, $97,393-405$. [CrossRef]

32. Kamboj, S.; Saroha, K.; Goel, M.; Madhu, C. Sustained release drug delivery system: An overview. Pharm. Res. 2012, 8, 169-186.

33. Krishna, A.V.; Kumaran, K.S.; Meena, A. Development and in vitro characteristics of bupropion $\mathrm{HCl}$ sustained release matrix tablets one. IJNTPS 2015, 5, 172-177.

34. Bankole, A.J. Naltrexone long-acting formulation in the treatment of alcohol dependence. Ther. Clin. Risk Manag. 2007, 3, 741-749.

35. Revision of Monograph on Tablets: Final Text for Addition to The International Pharmacopoeia. Available online: https:/ www. who.int/medicines/publications/pharmacopoeia/Tabs-GeneralMono-rev-FINAL_31032011.pdf (accessed on 17 April 2021). 
36. Vlachou, M.; Kikionis, S.; Siamidi, A.; Kyriakou, S.; Tsotinis, A.; Ioannou, E.; Roussis, V. Development and Characterization of Eudragit ${ }^{\circledR}$-Based Electrospun Nanofibrous Mats and Their Formulation into Nanofiber Tablets for the Modified Release of Furosemide. Pharmaceutics 2019, 11, 480. [CrossRef] [PubMed]

37. Khan, K.A. The concept of dissolution efficiency. J. Pharm. Pharmacol. 1975, 27, 48-49. [CrossRef] [PubMed]

38. Podczeck, F. Comparison of in vitro dissolution profiles by calculating mean dissolution time (MDT) or mean residence time (MRT). Int. J. Pharmaceut. 1993, 97, 1-3. [CrossRef]

39. Ritger, P.; Peppas, N. A simple equation for description of solute release II. Fickian and anomalous release from swellable devices. J. Control. Release 1987, 5, 37-42. [CrossRef]

40. Shah, V.P.; Tsong, Y.; Sathe, P.; Liu, J.P. In vitro dissolution profile comparison-statistics and analysis of the similarity factor, f2. Pharm. Res. 1998, 15, 889-896. [CrossRef]

41. Costa, P.; Sousa Lobo, J.M. Modeling and comparison of dissolution profiles. Eur. J. Pharm. Sci. 2001, 13, 123-133. [CrossRef]

42. Efentakis, M.; Iliopoulou, A.; Siamidi, A. Effect of core size and excipients on the lag time and drug release from a pulsatile drug delivery system. Drug Dev. Ind. Pharm. 2011, 37, 113-120. [CrossRef]

43. Markl, D.; Zeitler, J.A. A Review of Disintegration Mechanisms and Measurement Techniques. Pharm. Res. 2017, 34, 890-917. [CrossRef] [PubMed]

44. Kambham, V.; Kothapalli Bonnoth, C. Development of stavudine sustained release tablets: In-vitro studies. Futur. J. Pharm. Sci. 2016, 2, 37-42. [CrossRef]

45. Jain, A.K.; Söderlind, E.; Viridén, A.; Schung, B.; Abrahamsson, B.; Knopke, C.; Tajarobi, F.; Blume, H.; Anschutz, M.; Welinder, A.; et al. The influence of hydroxypropyl methylcellulose (HPMC) molecular weight, concentration and effect of food on in vivo erosion behavior of HPMC matrix tablets. J. Control. Release 2014, 187, 50-58. [CrossRef] [PubMed]

46. Tiwari, S.; Mahaparale, P. Effect of Hydrophilic and Hydrophobic Polymer on Sustained Release Matrix Tablet of Bupropion Hydrochloride. Int. J. Pharm. Sci. Res. 2013, 4, 2835-2842. [CrossRef]

47. Tiwari, S.B.; Murthy, T.K.; Pai, M.R.; Mehta, P.R.; Chowdary, P.B. Controlled release formulation of Tramadol Hydrochloride using hydrophilic \& hydrophobic matrix system. AAPS Pharm. Science Tech. 2003, 4, 18-23. [CrossRef]

48. Makhija, S.N.; Vavia, P.R. Investigated swellable as well as nonswellable polymers for sustaining the release of Venlafaxine. Eur. J. Pharm. Biopharm. 2004, 54, 9. [CrossRef]

49. Li, F.-Q.; Hu, J.-H.; Deng, J.-X.; Su, H.; Xu, S.; Liu, J.-Y. In vitro controlled release of sodium ferulate from Compritol 888 ATO-based matrix tablets. Int. J. Pharm. 2006, 324, 152-157. [CrossRef]

50. Maggi, L.; Bruni, R.; Conte, U. High molecular weight polyethylene oxides (PEOs) as an alternative to HPMC in controlled release dosage forms. Int. J. Pharm. 2000, 195, 229-238. [CrossRef]

51. Maggi, L.; Segale, L.; Torre, M.L.; Ochoa, M.E.; Conte, U. Dissolution behaviour of hydrophilic matrix tablets containing two different polyethylene oxides (PEOs) for the controlled release of a water-soluble drug. Dimensionality study. Biomaterials 2002, 23, 1113-1119. [CrossRef]

52. Wu, N.; Wang, L.-S.; Tan, D.C.-W.; Moochhala, S.M.; Yang, Y.-Y. Mathematical modeling and in vitro study of controlled drug release via a highly swellable and dissoluble polymer matrix: Polyethylene oxide with high molecular weights. J. Control. Release 2005, 102, 569-581. [CrossRef]

53. Lee, J.-H.; Kim, M.-J.; Yoon, H.; Shim, C.-R.; Ko, H.-A.; Cho, S.-A.; Lee, D.; Khang, G. Enhanced dissolution rate of celecoxib using PVP and/or HPMC based solid dispersions prepared by spray drying method. Int. J. Pharm. Investig. 2013, 43, 205-213. [CrossRef]

54. Vlachou, M.; Tragou, K.; Siamidi, A.; Kikionis, S.; Chatzianagnostou, A.L.; Mitsopoulos, A.; Ioannou, E.; Roussis, V.; Tsotinis., A. Modified in vitro release of the chronobiotic hormone melatonin from matrix tablets based on the marine sulfated polysaccharide ulvan. J. Drug Deliv. Sci. Technol. 2018, 44, 41-48. [CrossRef]

55. Papadopoulou, V.; Kosmidis, K.; Vlachou, M.; Macheras, P. On the use of the Weibull function for the discernment of drug release mechanisms. Int. J. Pharm. 2006, 309, 44-50. [CrossRef]

56. Bupropion. Available online: https://pubchem.ncbi.nlm.nih.gov/compound/444\#section=Melting-Point (accessed on 12 December 2020).

57. Naltrexone. Available online: https:// pubchem.ncbi.nlm.nih.gov/compound/Naltrexone\#section=Melting-Point (accessed on 12 December 2020).

58. Vlachou, M.; Siamidi, A.; Goula, E.; Georgas, P.; Pippa, N.; Karalis, V.; Sentoukas, T.; Pispas, S. Probing the release of the chronobiotic hormone melatonin from hybrid calcium alginate hydrogel beads. Acta Pharm. 2020, 70, 527-538. [CrossRef]

59. McKinney, A.A.; Tollefson, G.D.; Soltero, R.; Dunzo, T.E. Sustained Release Formulation of Naltrexone. U.S. Patent 8,916,195 B2, 4 June 2007.

60. Ghimire, M.; Hodges, L.A.; Band, J.; O’Mahony, B.; McInnes, F.J.; Mullen, A.B.; Stevens, H.N.E. In-vitro and in-vivo erosion profiles of hydroxypropylmethylcellulose (HPMC) matrix tablets. J. Control. Release 2010, 147, 70-75. [CrossRef] [PubMed]

61. Lamoudi, L.; Chaumeil, J.C.; Daoud, K. Swelling, erosion and drug release characteristics of Sodium Diclofenac from heterogeneous matrix tablets. J. Drug Deliv. Sci. Technol. 2016, 31, 93-100. [CrossRef]

62. Rowe, R.C.; Sheskey, P.J.; Quinn, M.E. Handbook of Pharmaceutical Excipients, 6th ed.; Pharmaceutical Press and American Pharmacists Association: London, UK; Chicago, IL, USA, 2009. 
63. Kar, R.K.; Mohapatra, S.; Barik, B.B. Design and characterization of controlled release matrix tablets of Zidovudine. Asian J. Pharm. Clin. Res. 2009, 2, 54-61.

64. Khamanga, S.M.; Walker, R.B. Evaluation of rate of swelling and erosion of verapamil (VRP) sustained-release matrix tablets. Drug Dev. Ind. Pharm. 2006, 32, 1139-1148. [CrossRef]

65. Efentakis, M.; Pagoni, I.; Vlachou, M.; Avgoustakis, K. Dimensional changes, gel layer evolution and drug release studies in hydrophilic matrices loaded with drugs of different solubility. Int. J. Pharm. 2007, 339, 66-75. [CrossRef]

66. Chaibva, F.A.; Khamanga, S.M.M.; Walker, R.B. Swelling, erosion and drug release characteristics of salbutamol sulfate from hydroxypropyl methylcellulose-based matrix tablets. Drug Dev. Ind. Pharm. 2010, 36, 1497-1510. [CrossRef]

67. Li, H.; Hardy, R.J.; Gu, X. Effect of drug solubility on polymer hydration and drug dissolution from polyethylene oxide (PEO) matrix tablets. AAPS Pharm. Sci. Tech. 2008, 9, 437-443. [CrossRef]

68. Zhang, F.; Meng, F.; Lubach, J.; Koleng, J.; Watson, N.A. Properties and mechanisms of drug release from matrix tablets containing poly(ethylene oxide) and poly(acrylic acid) as release retardants. Eur. J. Pharm. Biopharm. 2016, 105, 97-105. [CrossRef]

69. Apovian, C.M. Naltrexone/bupropion for the treatment of obesity and obesity with Type 2 diabetes. Future Cardiol. 2016, 12, 129-138. [CrossRef]

70. Yanovski, S.Z.; Yanovski, J.A. Naltrexone extended release plus bupropion extended release for treatment of obesity. JAMA 2015, 313, 1213-1214. [CrossRef]

71. Verpeut, J.L.; Bello, N.T. Drug safety evaluation of naltrexone/bupropion for the treatment of obesity. Expert Opin Drug Saf. 2014, 13, 831-841. [CrossRef]

72. Dhillon, S.; Yang, L.P.H.; Curran, M.P. A Review of its Use in the Management of Major Depressive Disorder. Adis. Drug Eval. 2008, 68, 653-689.

73. Modesto-Lowe, V.; Van Kirk, J. Clinical uses of naltrexone: A review of the evidence. Exp. Clin. Psychopharmacol. 2002, 10, 213-227. [CrossRef] [PubMed]

74. Dart, R.C. Medical Toxicology, 3rd ed.; Lippincott Williams \& Wilkins: Philadelphia, PA, USA, 2004; p. 854.

75. RxList. Available online: https://www.rxlist.com/naltrexone-hydrochloride-drug.htm (accessed on 17 April 2021).

76. Billes, S.K.; Sinnayah, P.; Cowley, M.A. Naltrexone/bupropion for obesity: An investigational combination pharmacotherapy for weight loss. Pharmacol Res. 2014, 84, 1-11. [CrossRef] [PubMed]

77. Heer, D. Novel Excipients As Different Polymers: A Review. J. Drug Deliv. Ther. 2013, 3, 202-207. [CrossRef]

78. Saeidipour, F.; Mansourpour, Z.; Mortazavian, E. Rafiee-Tehrani N and Rafiee-Tehrani M: New comprehensive mathematical model for HPMC-MCC based matrices to design oral controlled release systems. Eur. J. Pharm. Biopharm. 2017, 121, 61-72. [CrossRef] [PubMed]

79. Aparna, G.; Vijay, S.; Lalit, S. Process variable studies for preparation of optimized system for bupropion hydrochloride using CCD. J. Drug Deliv. Ther. 2019, 9, 281-290. [CrossRef]

80. Joshi, M. Role of Eudragit in Targeted Drug Delivery. Int. J. Curr. Pharm. Res. 2013, 5, 58-62.

81. Dhawan, S.; Varma, M.; Sinha, V.R. High molecular weight poly(ethylene oxide)-based drug delivery systems. Part I: Hydrogels and hydrophilic matrix systems. Pharm. Technol. 2005, 29, 72-80.

82. Dhawan, S.; Dhawan, K.; Varma, M.; Sinha, V.R. Applications of poly(ethylene oxide) in drug delivery systems. Part II. Pharm. Technol. 2005, 29, 82-96.

83. Bottenberg, P.; Cleymaet, R.; De Muynck, C.; Remon, J.P.; Coomans, D.; Michotte, Y.; Slop, D. Development and testing of bioadhesive, fluoride-containing slow-release tablets for oral use. J. Pharm. Pharmacol. 1991, 43, 457-464. [CrossRef]

84. Tukaram, B.N.; Rajagopalan, I.V.; Shartchandra, P.S.I. The Effects of Lactose, Microcrystalline Cellulose and Dicalcium Phosphate on Swelling and Erosion of Compressed HPMC Matrix Tablets: Texture Analyzer. IJPR 2010, 9, 349-358.

85. Cunha, L.; Grenha, A. Sulfated Seaweed Polysaccharides as Multifunctional Materials in Drug Delivery Applications. Marine Drugs 2016, 14, 1-41. [CrossRef] [PubMed] 